\title{
Beyond Politics in Bond's Lear
}

\author{
PERRY NODELMAN
}

There are two easy assumptions to make about Edward Bond's Lear. The first is that the play parodies Shakespeare's King Lear. The second, encouraged by Bond's preface to the play, is that it makes a political statement. In fact, most readings of Lear assume that Bond makes the political statement by means of the Shakespearean parody.

Some of Lear can indeed be explained this way. Lear's wall represents Shakespeare's idea of order. Shakespeare believed that monarchs had an obligation to keep order in the state; Bond's Lear says, " ... I built this wall to keep our enemies out. ... My wall will make you free." The irony is obvious. Lear's way of keeping his enemies out keeps his people in; and kept "inside a fortress" (p. 19), his people become his enemies.

Inside the wall, Lear's daughters Bodice and Fontanelle have grown up insulated from evil. So they cannot distinguish between evil and good, and are governed only by their whims. Lear's wall has made them, not good, but incapable of not being bad. Furthermore, in arrogantly assuming he has a right to protect others from ugliness and pain by keeping them inside a prison, Lear has created their understandable desire to be prison guards themselves.

Lear himself has also been corrupted by his wall. He interrupts his speech about how his people "are my sheep and if one of them is lost I'd take fire to hell to bring him out" (p. 2I) to fire on one of his "sheep" because he has slowed down work on the wall. His theoretically good idea blinds him to the implications of his actual behaviour. In fact, everyone who acts badly throughout the play has impeccably good reasons for doing so, most of them having to do with the preservation of social order. As Lear finally tells the old Councillor, "You good, decent, honest, upright, lawful men who believe in order - when the last man dies, you will have killed him" (p. 93).

In his preface, Bond suggests that his "Act One shows a world dominated by myth. Act Two shows the clash between myth and reality, between superstitious men and the autonomous world" (p. 12). Apparently "myth" means the 
ideas men live by. The map discussed in the first scene of Shakespeare's play shows King Lear's kingdom as he would like it to be; ironically, what the map depicts never comes to be. In Act Two of Bond's play, a soldier says, "We never come straight an' the maps is US" (p. 57). They represent reality even less than they once did. But they still have power; as Bodice says, "the map's my straitjacket . ... I'm trapped" (p. 62). Lear's wall is a futile attempt to impose the map of his ideas on the real surface of the earth; he even tries to build it across a swamp. Both walls and maps represent the futility of trying to impose human conceptions on the natural world; they imply an attack on the orderly values of Shakespeare's play.

But if Lear is only that, its characters must be only caricatures, one-sided representations of Bond's dislike for Shakespeare's political assumptions. To some extent they are that; but caricature is itself a sort of literary wall-building. Governed by a few obvious traits, caricatures cannot respond flexibly to experience. Bond dislikes wall-building; finally he makes us understand that his characters are inflexible, not because he chose to depict them that way, but because the values they live by have made them inflexible, and that they have the potential to be something more.

Imprisoned by the walls of myth, the Bodice and Fontanelle of Act One are distasteful caricatures of self-indulgence; as we see the clash between myth and reality in Act Two, Bond demands sympathy for them. Lear's evocation of the ghosts of his daughters' innocent youth shows how his actions have corrupted them; the helplessness of an imprisoned Fontanelle and the confusion of a Bodice straitjacketed by maps imply that even in maturity they are not merely despicable. If Bond's purpose were only satiric, his depiction of such moments is hard to understand.

Even harder to understand is his treatment of the Gravedigger's Boy. To begin with the Boy seems to represent right values. Lear stupidly tries to build his wall across a swamp, and turns life-giving water into a source of pain and death; inversely, when the Boy wisely realizes that the grave he is digging is actually a well, he accepts the fact: "I thought, there's water here and some land, why do I want to dig graves all my life? So I live here and built this farm" (p. 32). But after the corruption unleashed by Lear's wall-building muddies the waters of the Boy's well, and turns it into his own grave, the Boy's ghost gradually loses his original right understanding, until he finally says to Lear, "Let me poison the well .... Then no one can live here, they'll have to leave you alone" (p. 95). That Bond's spokesman should turn into another welldestroying wall-builder suggests that his intentions are more than propagandistic, and that the play is more than a dramatic representation of Bond's political ideas by means of a parody of Shakespeare.

Nevertheless, Bond's first act is a parody of Shakespeare's play, an ironic representation of the "myth" that governs King Lear. By the end of that act, Bond's Lear has lived through ironic versions of everything that happens to Shakespeare's king throughout King Lear. After that, something different 
happens. Lear moves beyond caricature and becomes a tragic hero in his own right.

In both King Lear and Act One of Lear, Lear loses his kingdom to his daughters, is helped through a period of madness by a selfless person of no social standing, seems to realize his guilt, and finally, sees someone whose right understanding he has learned to admire killed by his own original bad actions. But while the events are the same, the effect is different.

Shakespeare creates sympathy for his Lear; Bond wants none. When Shakespeare's Lear acts like his old self in defiance of new circumstances, our admiration for his regality makes us pity him. When Bond's Lear does the same thing, he is a cruel caricature of regal arrogance: "I've seen armies on their hands and knees in blood, insane women feeding dead children at their empty breasts, dying men spitting blood at me with their last breath, our brave young men in tears - . But I could bear all this" (p. 2I). The excessive rhetoric makes the irony obvious; Lear himself has borne nothing, and understood nothing. He even says, "it's too late to learn anything" (p. 2I).

In fact, he keeps saying something like that throughout the act. Shakespeare's Lear learns through suffering; the action of the play is a process of redemption. Bond's Lear learns nothing because his Shakespearean ideas of order keep causing him to misunderstand what he thinks he has learned.

When Shakespeare's Lear is left on his own, his growing consciousness of his own human weakness leads him to pity others. When Bond's Lear is left on his own, he too discovers his weakness: "... I am a famished dog that sits on the earth and howls .... They lock the door of my coffin and tell me to die" (p. 3I). Having truly suffered, he sees beyond his earlier conviction that he had borne all there was to bear, and his language is simple enough to sound convincing. But ironically, his response to his new knowledge is to believe yet again that now he has borne all there is to bear; rather than feel pity for the suffering of others, he merely demands the peace of death: "I'm old and too weak to climb out of this grave again" (p. 3I).

Shakespeare's Lear expresses a similar statement. He tells Cordelia, "You do me wrong to take me out o' th' grave ... " (IV, vii, 45). ${ }^{2}$ But he says it only after he has suffered almost all he will suffer; and I think we are meant to agree that he has suffered enough. Apparently Bond does not agree. His Lear makes his speech about the grave before he experiences the horrors of the rest of the play. Bond implies that Shakespeare's Lear learned much "wisdom" from comparatively little pain, that to believe one has suffered enough is always an act of arrogance, and that in any case, what King Lear learned was not truly wise.

What he learned was his obligation to keep the world orderly and prevent suffering. Bond's Lear believed that all along; it was the source of his suffering. So he acts on the new wisdom he thinks he has learned in the same way he acted on the old wisdom. When, after being helped through madness by the Boy, he says, "I should have spent my life here" (p. 38), he sounds correct. The Boy 
knows how to live, and Lear wants to live like the Boy. But Bond shows that Lear does not really understand by having him add, "It's so simple and easy here .... I could have a new life here. I could forget all the things that frighten me .... I've been too trusting, too lenient" (p. 39). Lear admires the Boy's life for the wrong reasons; he thinks it will prevent suffering, just as he earlier believed his wall would prevent suffering. And instead of wanting to tear walls down, he wants to build them stronger; he helps the Boy's wife make a wall of sheets in the midst of paradise, and still trying to keep his enemies out, he says to her, "You go! It's you who're destroying this place" (p. 4I).

Bond suggests that the end of his first act parallels the end of Shakespeare's play by recalling the last moments of Shakespeare's Lear. Lear, holding the body of the dead Cordelia, says, "Look on her, look, her lips, / Look there, look there" (V, iii, 3IO-II ). As Bond's first act nears its end, the Boy holds the body of the dying Warrington, and says, "My God! - he's breathing. There's bubbles on his mouth! Look!" (p. 43), and then, for the first time in the play, speaks his wife's name: "Cordelia!" The scene is a cruel parody of Shakespeare's; the Boy, who wanted to live and knew how to live, dies instead of Lear himself, who wrongly thought he knew how to live and believed he deserved to die. And the event starts Cordelia toward the behaviour that will make her deserve her name. Instead of dying, she comes to life as Lear's "real" daughter, the person who acts as he once did; horrified by evil, she will work to eradicate it.

By ironic implication, Bond shows the flaws in Shakespeare's myth; having gone through everything Shakespeare's Lear suffered, Bond's Lear learns nothing at all. He learns nothing because he cannot stop wall-building; no matter what he experiences, he still thinks right behaviour prevents suffering. But by the end of Act One, the walls have been breached. The sheets tumble in a sea of blood, as Lear's attempt to build walls around the good life destroys it.

As Act Two begins, Lear echoes his earlier speech about the freedom found behind walls: " ... Take me back to my prison. We are freer there" (p. 47). But now he intends it ironically; now he has really suffered, and can begin to learn. Act Two takes him through a series of realizations to true understanding, as "reality" replaces "myth." But Bond never lets Lear off lightly; each time he gets closer to the truth, he thinks he knows the whole truth. Constantly building walls around his new understanding, he makes impressive statements that sound wise and imply his right to be excused from further pain; he discovers to his increasing horror that he is not yet truly wise, and not yet through with pain.

His first realization is that prisons do not create freedom. Seeing his own image in a mirror, he says, "No, that's not the king ... This is a little cage of bars with an animal in it .... Who shut that animal in that cage? Let it out" (p. 49). It is his own image he sees, himself he understands to be imprisoned, himself he pities and wants freedom for; but ironically, genuine self-pity is an advance for Lear. He finally realizes that wall-building has personal implications as well as the social ones depicted in Act One. He no longer wants the "freedom" of 
prison, for he finally sees that he is indeed imprisoned, and that it causes him pain.

Nevertheless, he responds to his new knowledge with his old mental habits; he tries to blot it out. "Kill it," he says of his own image, "I can't live with that suffering in the world" (p. 49). And he attempts a further escape, this time into a nostalgic vision of a world without suffering. He evokes the ghosts of people who no longer exist, the Gravedigger's Boy and his own daughters as young girls. For Lear, these ghosts represent an innocence no longer available.

But ironically, Lear's attempted escape into a happier past makes him see the ugly implications of his own past actions. He says to his daughters' ghosts, "Stay here .... We can stay here together" (p. 55). But they cannot stay, for his earlier attempts to make them stay behind walls and innocent of reality have already murdered them, and replaced them with an older and crueller Bodice and Fontanelle. And Lear's wall-building killed the Boy too. These are literally ghosts of Lear's creation. In trying to escape a world made ugly by his own actions, he is forced to re-evaluate those actions, and acknowledge their painful implications: "I shouldn't have looked. I killed so many people and never looked at one of their faces. But I looked at that animal. Wrong. Wrong. Wrong. It's made me a stupid old man" (p. 56). The arrogant old Lear still wants to ignore his new knowledge; but the new Lear who knows it acts on it. "Stupid" in his new understanding of his own suffering and his own guilt, he seems to understand the suffering of others, and says to the Boy's ghost, "We'll help each other" (p. 56).

But Lear's pity is still self-centred, expressed only for figments of his own imagination. In comforting the Boy, Lear is only easing his new sense of guilt. He obviously has more to learn; but once more he thinks he knows the whole truth, and believes he deserves freedom from suffering, this time in terms of his new humility: "why do they waste their life leading an old man on a rope?" (p. $65)$.

Lear quickly learns the inadequacy of this humility. Having left the prison he built around himself, he now sees what is outside it: "There was so much sky. I could hardly see. I've always looked down at the hills and banks where the enemy was hiding. But there's only a little strip of earth and all the sky" (p. 69). Lear realizes how stupid he was to try to control a world, so utterly without significance; but he does not know the right way to use his new knowledge. While it allows him to accept the actual Fontanelle instead of the ghost of a dead one without his old rancour, that seems to be because he feels nothing at all. Fontanelle reaches out to Lear in her own new wisdom, caused by her own suffering, that she is herself "a stupid woman" (p. 7I), just as he earlier admitted he was a stupid man. But caught up in his rhetoric about the "little strip of earth," Lear does not even hear her. A step beyond her on the way to truth, he seems to have decided that the inhabitants of the "little strip" are simply not worthy of attention. Once more Lear builds a wall, this time against emotion. 
Once more, pain breaks down the wall, as Lear views the organs of the dead Fontanelle: "She sleeps inside like a lion and a lamb and a child. The things are so beautiful. I am astonished .... If I had known this beauty and patience and care, how I would have loved her" (p. 73). While the world men inhabit is small, that should engender, not lack of interest in our problems, but infinite concern for our fragile beauty. Lear asks, "Did I make this - and destroy it?" He did both, of course; and he destroyed her by believing he could make her better than she already was. In acknowledging that, Lear understands what he did not understand all along - that the world as it is and the people in it are more wonderful than anything one might make them.

In his new understanding, Lear says, "I destroyed her! I knew nothing, saw nothing, learned nothing .... I must open my eyes and see!" (p. 74). Again, this sounds good; Lear admits guilt, and acknowledges his own involvement with the rest of humanity. But his excessive language suggests yet again that Lear does not know how to use his new knowledge. Knowing that suffering teaches wisdom, Lear resolves to suffer. His conviction that "I must walk through my life, step after step, I must walk in weariness and bitterness ..." (p. 74) is a perverse escape from reality. Lear wants to build a wall around his suffering and do nothing but suffer.

This time he learns his lesson quickly. He "opens" his eyes only to have them put out. He gets what he thought he wanted, and he does not like it. It does not make him feel better or less guilty or more accepting. He only wants to escape it: "Take me somewhere to die!" (p. 78).

Finally, Lear has come to understand that wisdom is not a way of preventing pain, but an acceptance of its inevitability. But as Act Two ends, he tries to dissuade a farmer's son from becoming a soldier fighting to create a better world. He cannot do it, and he says, "I could learn to endure my blindness with patience, I could never endure this!” (p. 80). What Lear cannot endure is that, while his suffering has made him wise, no one else will make his suffering meaningful by learning from his wisdom.

In fact, that is what Act Three is about. Early in the act, Lear tells a parable about a bird whose beautiful song turns to groans when it is caged by a man who admires its beauty, and about how its pain is felt by the man who caged it. For Lear, this story is about wall-building, and he refuses to build walls (or cages) anymore: “... I won't send anyone away. That's how I'll end my life. I'll be shut up in a grave soon, and till then this door is open" (p. 88). But ironically, the very people he opens the door to say, "We can't let everyone in," and those who hear Lear's parable think it a call to action against the current government. Tortured by their blindness, Lear says, "If I saw Christ on his cross I would spit at him" (p. 90). Like Christ, he has preached a Sermon on the Mount. Like Christ, he has suffered greatly, and wants his suffering to benefit mankind. But Christ died believing his suffering was redemptive; Lear learns his can help no one but himself: "What can I do? I left my prison, pulled it down, broke the key, 
and still I'm a prisoner. I hit my head against a wall all the time. There's a wall everywhere. I'm buried alive in a wall" (p. 94).

This is truer than Lear knows; he still wants people to live by his truth, and he must see the error in that. Even if, unlike his earlier ideas, his new truth is actually true, he still wants to build walls around the experience of other people. That is why he is "buried alive in a wall." He must learn to do what the Boy's ghost suggests: "Let them learn to bear their own sufferings" (p. 94). The plural is suggestive; everyone's suffering is different from everyone else's suffering, and no one can learn how to cope with his own suffering from anybody else's experience.

That Lear must understand that suggests how far the play moves beyond Bond's preface to it. The preface is a political act; like Lear's parable, it tries to persuade people of the right way to live. Bond says, "We do not need a plan of the future, we need a method of change" (p. II). But by the time the play ends, Lear's life has made it clear that no social change is possible, that true wisdom is always bought with hard personal experience, and that any attempt to improve the lives of other people is both futile and dangerous. The play speaks passionately against political activity of any sort. All Lear can do is accept the world as he has come to see it.

While that seems a bleak conclusion, the end of Lear is not bleak. Lear's final realization is this: "I see my life, a black tree by a pool. The branches are covered with tears. The tears are shining with light. The wind blows the tears in the sky. And my tears fall down on me" (p. IOO). In a final redeeming irony, the tears of suffering become rain, the source of new life. Lear has found his way out of the desert he dreamed of in Act One, a desert created by those who dig up the life-giving sea in order to get rid of its howling - who try to eliminate tears and eliminate life. In accepting tears as inevitable, Lear makes them lifegiving. He interferes in the lives of others no more, no longer tries to protect them from pain, and commits himself to a truly life-affirming act of suffering. He makes the gesture of tearing down the wall he started to build. Since he has no audience, and knows his action will quickly cause his own death, it is anything but a political statement. It is a personal gesture Lear makes for himself, a stand taken against the wall-building tendencies of all political philosophies - including Edward Bond's.

Finally, then, Lear transcends both its parodistic elements and its political intentions, and becomes a tragedy that makes as much sense for our time as Shakespeare's did for his. The effect of Shakespeare's play depends on acceptance of the values that underpin it. Those ideas no longer have the force they once did; the maps no longer describe the territory. As Lear tells Cordelia, "If a god had made the world, might would always be right, that would be so wise, we'd be spared so much suffering. But we made the world - out of our smallness and weakness. Our lives are awkward and fragile and we have only one thing to keep us sane: pity, and the man without pity is mad" (p. 98). In 
Shakespeare's cosmology, God did make the world, and made it in a way that demanded cleaving to ideas of order; in Bond's cosmology, he did not.

Nevertheless, Lear's statement about pity is not the whole truth. Its excessive rhetoric implies its failure; and shortly after saying it, Lear gives up the ghost that represents his pity for the fragility of mankind and his obligation to help those weaker than himself. He tells the Boy to die "for your own sake ..." (p. I00), and he says, with simplicity, "my tears fall down on me," not on mankind; in doing so, he realizes that self-pity is finally what really matters. His acceptance of his own awkwardness and fragility frees him from the arrogant need to pity and try to improve the lives of others that Bond sees as the source both of evil and of politics.

Bond's ideas about pity and politics are unusual; but admiration of Lear does not depend on agreement with its meaning. The play is anything but propaganda. It does not tell us how to live; every apparent statement of truth it contains is qualified by what happens before it, or during it, or after it. I do not know why Bond should so misrepresent his own work in his preface; but the play itself suggests that his instincts are more those of a dramatist than they are those of a propagandist. The mere existence of Act Three of Lear, in which Lear learns to die for his own sake and not for the good of mankind, is an ironic comment on the political enthusiasms Bond professes.

NOTES

I Edward Bond, Lear, in Plays: Two (London, 1978), pp. I7-18. All further references to Lear are to this Eyre Methuen edition and will appear in the text.

2 William Shakespeare, King Lear, ed. Kenneth Muir (London, I963). All further references to King Lear are to this Arden edition and will appear in the text. 